\title{
Za docentem Mirkem Čejkou
}

Oslovoval své studenty „dámy a pánové“ v době, kdy to rozhodně nebylo běžné, vzbuzoval $\mathrm{v}$ nich pocit, že patřit $\mathrm{k}$ akademické obci něco znamená a také to zavazuje, několika generacím adeptů bohemistiky na brněnské filozofické fakultě poodhalil tajemství jazyka a uvedl je do dobrodružství lingvistiky. V závěru roku 2017 všechny zaskočila a zarmoutila zpráva o jeho smrti.

Docent Mirek Čejka narozený v Olomouci, prožil štastné dětství v Bystřici pod Hostýnem, kam se celý život vracel a kde se s ním také jeho blízcí naposled rozloučili. Rodinné prostředí váženého bystřického učitele naznačilo i směr Čejkovy budoucí profesní dráhy. Po absolvování gymnázia ve Valašském Meziříćí získal v letech 1949-1953 vysokoškolské vzdělání na Filozofické fakultě Masarykovy univerzity v Brně, kde vystudoval dvojobor čeština a ruština. Na fakultě, která se později měla stát i jeho domovským pracovištěm, ho ovlivnila řada významných osobností, např. bohemisté Adolf Kellner a František Trávníček, v jejichž semináři byl už jako student zapojen do vědecké práce. Budoucí Čejkovo odborné zaměření, přesahující od bohemistiky a slavistiky k obecné i srovnávací jazykovědě, významně formovaly také přednášky a semináře slavisty Josefa Kurze a indoevropeisty Václava Machka. Velkou část svého lingvistického vzdělání však Čejka získal soustředěným celoživotním samostudiem a otevřeností ke všem novým impulzům, zejména zahraničním, jejichž recepci mu umožňovala kvalitní jazyková vybavenost.

Po ukončení vysoké školy Mirek Čejka krátce působil jako středoškolský pedagog. Už v roce 1954 však nastoupil do dialektologického oddělení nově vytvořené pobočky Ústavu pro jazyk český ČSAV v Brně, kde se podílel na výzkumné fázi př́ípravy Českého jazykového atlasu. Tato zkušenost mu přinesla celoživotní úctu k jazykovému materiálu, a přestože ve své pozdější práci tíhl spíše k teoreticky a filozoficky orientovaným lingvistickým tématům, pokora před jazykovou materií v něm zůstala a vedl k ní i své studenty.

V letech 1956-1958 se Čejka ujal lektorátu češtiny při Ústavu pro cizí jazyky v Pekingu, což se stalo iniciačním krokem pro jednu z oblastí jeho pedagogického působení - výuku češtiny pro cizince. Své zahraniční lektorské pobyty (kromě Pekingu to byly ještě v letech 1966-1968 Londýn a 1993-1994 Řezno) využil i jako možnost k získání nových vědomostí, které následně uplatnil ve své vědecké a pedagogické praxi. Na brněnské filozofické fakultě vedl např. kurzy věnované čínštině a orientální filozofii, díky svému fundovanému vhledu do anglo-americké odborné literatury poskytoval českým studentům (a svou recenzní a překladatelskou činností i širší lingvistické obci) cenné informace o málo známých či neznámých světech filozofie jazyka, sémiotiky, kognitivní sémantiky či pragmalingvistiky. 
Pedagogické působení na mateřské filozofické fakultě zahájil Mirek Čejka v záŕí 1959, kdy nastoupil jako odborný asistent na Katedru českého jazyka, slovanské, indoevropské a obecné jazykovědy Filozofické fakulty UJEP (dnes MU) v Brně. Ve škále jím vedených kurzů dominovaly přednášky a semináře uvádějící posluchače do jazykovědné bohemistiky a obecné lingvistiky a do problematiky lexikologické. Pro ně zpracoval i řadu kvalitních a autorsky výrazných učebních textů. Ty z poslední doby studenti rádi užívají dodnes: Úvod do studia jazyka pro bohemisty (1981, 1987), Úvod do studia jazyka (pro bohemisty) (1996), Česká lexikologie a lexikografie (1992).

Práci vysokoškolského učitele bral Čejka vždy jako poslání a přistupoval k ní s velkou odpovědností, vnitřním zaujetím i vnějším šarmem. Učil své žáky vnímat jazyk, přemýšlet o něm, „rozbalovat jeho balíčky“, jak říkal v lexikologii. Studenti si ho vážili pro šíri odborných znalostí a oceňovali, že je ve své době v podstatě jako jediný seznamoval s lingvistikou západního světa. Oblíbený byl také proto, že ve svých žácích už od prvního ročníku viděl partnery, diskutoval s nimi, učil je kritickému přemýšlení a bral vážně jejich názor.

Šíře Čejkova odborného rozhledu a otevřenost k pluralitě teorií a metodologických př́istupů neurčovaly jen náplň a charakter jeho práce pedagogické, ale i tematické rozpětí jeho badatelských a publikačních aktivit. ${ }^{1}$ Ve svých statích se prezentoval jako bohemista, slavista, indoevropeista, sinolog, ale především jako fundovaný obecný lingvista, se značnou průpravou v oblasti logiky a filozofie. Zajímala ho např. chronologie vzniku a diferenciace jazyků z pohledu nostratické teorie a za využití lexikostatistických metod, problematika významu v kontextu filozofickém i kognitivním, otázky pragmalingvistické, ale též tradičnější témata z oblasti dějin slavistiky, gramatografie, translatologie ad.

Přes kvalitu své vědecké a pedagogické práce nemohl Mirek Čejka vzhledem k dobovému politickému ovzduší absolvovat postgraduální studium, byt se nad ním snažil držet ochrannou ruku profesor Arnošt Lamprecht. Také habilitaci Čejkovi umožnila až změněná situace po listopadu 1989. Titul docent získal na FF MU v roce 1994 na základě obhájení habilitačního spisu Přání jako intencionální stav a mluvní akt.

Na brněnské filozofické fakultě působil docent Mirek Čejka až do svého odchodu do důchodu v roce 1995. Ani poté však nezůstal nečinný, ba právě naopak. I nadále připravoval v široké tematické škále př́spěvky pro domácí i zahraniční odborný tisk, nevyhýbal se ani článkům překračujícím hranici mezi úzkou odborností a popularizací či osvětou, nekompromisně se vyslovoval i k důležitým společenským otázkám (např. některá jeho vyjádření o stavu českého školství publikovaná po roce 2004 v časopise Host se zdají být každým dnem aktuálnějšími). Nejvíce pozornosti a sil však v této době věnoval editaci starých textů, při níž

1 Reflektovat více než 190 položek Čejkovy publikační činnosti není v této krátké vzpomínce možné. Shrnutí a charakteristiku jeho stěžejních prací napsaných před rokem 1999 podává stat' Zdeňky Hladké a Marka Nekuly Životní jubileum Mirka Čejky, SaS, 60 (1999), č. 4, s. 327-329. Souhrnný seznam publikací M. Čejky, který laskavě poskytla doc. Eva Pallasová, obsahuje 192 položek (nejsou započteny dvě práce $\mathrm{v}$ tisku). Dosud byly otištěny dva dílčí bibliografické přehledy, které sestavil sám M. Čejka: Soupis prací Mirka Čejky do roku 1990, SPFFBU, A $37-38$ (1989/90), s. 914; Dodatek k soupisu prací Mirka Čejky, SPFFBU, A 52 (2004), s. 177179. Doplňující pokračování bibliografie je uvedeno v závěru tohoto př́spěvku. 
kombinoval lingvistický zájem s hlubokým vnořením do historického, kulturního i myšlenkového kontextu zpracovávaných děl.

Editorské aktivity představují v celoživotním Čejkově působení důležitou linii, jejíž začátek se pojí už s edicí Gramatiky české Jana Blahoslava (1991, společně s Dušanem Šlosarem a Janou Nechutovou). K té se vrátil i po odchodu do důchodu, když na svém blogu prezentoval její pečlivě zrevidovanou verzi, doplněnou o nové komentáře a rozšířený úvod informující mj. o nelehkém vzniku edice.

Čejka se věnoval i řadě dalších edičních projektů. Jmenujme např. v roce 1999 publikovaný soubor Adam Michna z Otradovic, Básnické dílo. Texty písní 1647-1661, v němž revidoval dřívější Škarkovu edici tří písňových sbírek předního barokního skladatele (mj. na základě relativně nového nálezu tištěného textu jedné z nich - Loutny české), nebo první edici dvou textů důležitých pro dějiny utrakvismu ve stř̌ední Evropě Dvě staročeská utrakvistická díla Jakoubka ze Stř́bra (2009), kterou připravil s Helenou Krmíčkovou.

Pokračoval i Čejkův téměř celoživotní zájem o Blahoslavovy práce. V roce 2013 vychází v jeho ediční úpravě a s komentářem Hany Bočkové publikace Jan Blahoslav: Čtyři menší spisy. $\mathrm{V}$ př́padě posledního ze čtyř textů, Vitia concionatorum, šlo o první rádnou kritickou edici této významné památky z období českobratrského humanismu. Čejka svou práci na edicích provázel vždy i analytickými studiemi, např. z jazykového materiálu Vad kazatelů čerpala jeho stat Terminologie in statu nascendi ve Vadách kazatelů Jana Blahoslava (2012), začátkům českého zájmu o gramatický systém češtiny a zároveň místu Blahoslavovy gramatiky ve vývoji českého mluvnictví byl věnován př́spěvek Kořeny české gramatografie (2009).

Mirek Čejka byl odborně činný a neobyčejně svědomitý až do posledních měsíců svého života. I přes zdravotní problémy připravil ještě do tisku edici spisu Historia pravdivá o některých zvláštních věcech a divných Božích skutcích v světě, obzvlaštně pak př̀i Jednotě bratrské stálých a do sborníku k jubileu zahraničního kolegy prríspěvek Jezuitéa Jednota bratrská po Šmalkaldské válce (Případ Jana Augusty a Jakuba Bílka).

Zarmucuje nás vědomí, že pan docent Mirek Čejka, dlouholetý člen bohemistického pracoviště Filozofické fakulty Masarykovy univerzity, uznávaný lingvista a studenty ctěný a milovaný učitel, už není mezi námi. Budeme na něho s úctou a vděčností vzpomínat a zůstaneme mu vděčni za vše, co nás naučil.

\section{Zdeňka Hladká}

Department of Czech Language

Masaryk University, Faculty of Arts

Arna Nováka 1, 602 oo Brno

Czech Republic

zdena@phil.muni.cz 


\section{Závěrečný dodatek k soupisu prací Mirka Čejky²}

(navazuje na SPFFBU A 37-38, 1989-1990, s. 9-14; SPFFBU A 52, 2004, s. 177-179)

2004

ČEJKA, Mirek. Alma Mater - vdova po duchu. Host. Ohlasy. Brno: Spolek přátel vydávání časopisu Host, 8, s. 111-112.

ČEJKA, Mirek. Dodatek k soupisu prací Mirka Čejky: (navazuje na SPFFBU A 37-38, 19891990, s. 9-14). In: Sborník prací Filozofické fakulty brněnské univerzity. A, Řada jazykovědná. Brno: Masarykova univerzita, s. 177-179.

ČEJKA, Mirek. Jazyk mateřský a jazyk otcovský. Vztahy mezi češtinou, němčinou a latinou na přelomu středověku a novověku. In: Život s morfémy: sborník studií na počest Zdenky Rusínové. Brno: Masarykova univerzita, s. 35-46.

2005

ČEJkA, Mirek. Rozvoj české gramatografie od M. Jana Husa po Josefa Dobrovského. In: Přednášky a besedy z XXXVIII. běhu LŠSS. Brno: Masarykova univerzita, s. 14-23.

\section{6}

ČEJkA, Mirek. Česká jazykověda od M. Jana Husa po Josefa Dobrovského (Rozvoj gramatografie v našich zemích). In: Přednášky a besedy z XXXIX. běhu LŠSS. Brno: Masarykova univerzita, s. 16-25.

2007

ČEJKA, Mirek. K významové výstavbě Poláčkovy válečné tetralogie. In: Karel Poláček a obraz první světové války v české literatuře: sborník ze sympozia Karel Poláček a obraz první světové války v české literatuře, Rychnov nad Kněžnou - květen 2007. Boskovice: Albert, s. 17-25.

ČEJKA, Mirek. Tři výročí Theodora Čejky. Obec Chvalčov oznamuje. 39(5), s. 18-20.

ČEJKA, Mirek. Tři výročí Theodora Čejky. Zpravodaj města Bystřice pod Hostýnem. Bystřice pod Hostýnem: Město Bystřice pod Hostýnem, 34(12), s. 26-28.

ČEJKA, Mirek. Výchova? Vzdělání? Čert nám pomáhej! Host. Glosy. Brno: Spolek přátel vydávání časopisu Host, 8, s. 85.

2008

ČEJKA, Mirek. Lidé a válka v románech Karla Poláčka (Příspěvek k analýze smyslu literárního díla). In: Kontexty literární vědy I. Ústí nad Orlicí: Oftis, s. 75-94.

\section{9}

ČEJKA, Mirek. Kořeny české gramatografie. In: Pokušení Jaroslava Kolára: sborník k osmdesátinám. Praha: FF UK a ÚČL AV ČR, v. v. i., s. 90-100.

$2 \quad$ Na základě podkladů poskytnutých doc. Evou Pallasovou. 
ČEJKA, Mirek - LEHEČKa Dalibor. Josef Dobrovský: Deutsch-böhmisches Wörterbuch I-II. In: Vokabulář webový, Nezapojené zdroje [online]. Praha: Oddělení vývoje jazyka, ÚJČ AV ČR, v. v. i. Copyright 2006-2017. Dostupné z: http://vokabular.ujc.cas.cz/nezapojene.aspx?i$\mathrm{dz}=\mathrm{DDBW}$

ČEJKA, Mirek - KRMíčKovÁ, Helena, eds. Jakoubek ze Stř́bra: Dvě staročeská utrakvistická díla Jakoubka ze Stř́bra. Brno: Masarykova univerzita. 140 s. Spisy Masarykovy univerzity v Brně - Filozofická fakulta, č. 379.

ČEJKA, Mirek - PALlasová, Eva. Recenze: Tilman Berger, Studien zur historischen Grammatik des Tschechischen. Bohemistische Beiträge zur Kontaktlinguistik [= Travaux linguistiques de Brno, Vol. 2]; Josef Vintr, Studien zur älteren tschechischen Grammatographie [= Travaux linguistiques de Brno, Vol. 3]. Slavia. Praha: Slovanský ústav AV ČR, v. v. i., 80 , s. 14-17.

\section{2}

ČEJKA, Mirek. Čínské písmo. Typologický a historický pohled. In: Dialog. České Budějovice: Jihočeská univerzita, s. 29-52.

ČEJKA, Mirek. Terminologie in statu nascendi ve Vadách kazatelů Jana Blahoslava. In: Diachrone Aspekte slavischer Sprache: für Ernst Hansack zum 65. Geburtstag. München: Verlag Otto Sagner, s. 117-128.

\section{3}

ČEJKA, Mirek, ed. JaN BLAHosLav: Čtyři menší spisy. Brno: Host. 320 s. Česká knižnice (Host).

ČEJKA, Mirek. Čas a potenciálnost jako součásti mluvního aktu přání. In: Slavjanskite ezici otblizo. Sbornik v čest na 70-godišninata na doc. Janko Bǎčvarov. Sofija: Univ. Sv. Kliment Ochridski, s. 333-340.

\section{4}

ČEJKA, Mirek. Grammatikschreibung bei den Tschechen und Slowaken bis zur Aufklärung. In: Die slavischen Sprachen: Ein internationales Handbuch zu ihrer Struktur, ihrer Geschichte und ihrer Erforschung = The Slavic Languages: An International Handbook of their Structure, their History and their Investigation. Berlin, New York: Walter de Gruyter, s. 1812-1828.

LAKoff, George - Johnson, Mark. Metafory, kterými žijeme. Vyd. 2. Přeložil Mirek ČEjKA. Brno: Host. 284 s. Teoretická knihovna.

\section{8}

ČEJKA, Mirek. Jezuité a Jednota bratrská po Šmalkaldské válce (Př́ípad Jana Augusty a Jakuba Bílka). (V tisku.) 
ČEJKA, Mirek, ed. Historia pravdivá o některých zvláštních věcech a divných Božích skutcích v světě, obzvlaštně pak při Jednotě bratrské stálých. (V tisku. Zatím dle informace doc. Pallasové dostupné na: https://www.mirekcejkaa.wordpress.com.)

\section{Zdeňka Hladká}

Department of Czech Language

Masaryk University, Faculty of Arts

Arna Nováka 1, 602 o० Brno

Czech Republic

zdena@phil.muni.cz 